\title{
Comparative Analysis of Two Seaports in the Baltic-Adriatic Corridor
}

\section{Marina Zanne ${ }^{a}$, Przemystaw Borkowski ${ }^{b}$}

Ports are complex systems that have an essential role in the transportation of freight and indisputable importance for economies worldwide. Port operation requires many resources, and their performance depends on various factors.

This paper focuses on the Port of Koper in the Adriatic Sea, and the Port of Gdansk in the Baltic Sea. Two ports located in two very different countries, yet with similar recent history, are connected by the Baltic-Adriatic corridor.

The authors have compared the recent development of these ports through the analysis of five elements, and determined that better strategic measures have been taken in the Port of Gdansk, resulting in the faster development of the port and the opportunity to further improve its performance by strengthening its position on the Central European markets. Koper could learn how to further stabilize its position in the North Adriatic region from the model employed by the Port of Gdansk.

\section{KEY WORDS \\ $\sim$ Seaport \\ $\sim$ Poland \\ $\sim$ Slovenia \\ $\sim$ Port development factors \\ $\sim$ Comparative analysis}

\author{
a. University of Ljubljana, Faculty of Maritime Studies and Transport, Portorož, \\ Slovenia \\ e-mail: marina.zanne@fpp.uni-lj.si \\ b. University of Gdansk, Faculty of Economics, Sopot, Poland \\ e-mail: przemyslaw.borkowski@ug.edu.pl \\ doi: 10.7225/toms.v10.n01.013 \\ This work is licensed under (cc) BY
}

Received on: Oct 2, 2020 / Revised on: Nov 28, 2021 / Accepted on: Dec 9, 2021 / Published online: Feb 1, 2021
Reorganization is required to make Koper more competitive and capable of attracting fresh money. Also, the state should be much more supportive of the Port of Koper.

\section{INTRODUCTION}

Ports are complex systems that have an essential role in the transportation of freight; in fact, 11 billion tonnes of goods are transported by sea annually. In the pre-Covid-19 time, the international maritime trade was expected to grow, with an average annual growth rate of $3.5 \%$ in 2019-2024 (UNCTAD, 2019). Although Covid-19 halted this trend, the trade will start to grow after the pandemic and put even more pressure on ports and their hinterland as ever bigger ships carrying increasingly greater quantities of cargo come pouring in.

Ports are facilitators of trade, and create substantial added value in their home regions. Many factors influence the development of the port and its position in the global context; port's infrastructure and equipment, port's efficiency, sea access, location of the port, port's hinterland accessibility, port charges and the costs of auxiliary services, port's reputation, etc. (e.g., Slack,1985 or Tongzon, 2002). Or, according to Alderton (2008): demand, which is affected by changes in trade patterns and competition, inland transport, cargo handling technology, environmental pressures and port management.

The ports analysed in this paper, the Port of Koper and the Port of Gdansk, are situated in two countries with similar recent histories; both were rather closed and centrallydeveloped before the democratic transition of the 1990s, and both joined the European Union (EU) at the same time, in 2004. Today, they have similar corruption indices and competitive rankings (CountryEconomy, 2020), and are members of the same organisations, namely the EU, the North Atlantic Treaty Organization (NATO), the Organisation for Economic Co- 
operation and Development (OECD), the International Monetary Fund (IMF), the Organization for Security and Co-operation in Europe (OSCE), the European Economic Area (EEA) and the
Council of Europe (CoE), with Slovenia also belonging to the Euro Area (EA). Regardless of these similarities, they are different in many aspects, in particular those listed in Table 1.

Table 1.

Comparison of Slovenia and Poland in 2019.

Source: (CountryEconomy, 2020)

\begin{tabular}{lll} 
& Slovenia & Poland \\
\hline Area & 20,675 & 312,680 \\
\hline Population & $2,095,861$ & $37,958,138$ \\
\hline Annual GDP & $\$ 53,743$ million & $\$ 590,014$ million \\
\hline GDP per capita & $\$ 25,643$ & $\$ 15,544$ \\
\hline Debt ( \%GDP) & $66.1 \%$ & $46.0 \%$ \\
\hline Debt per capita & $\$ 16,956$ & $\$ 7,241$ \\
\hline Expenditure & $\$ 248,901.5$ million & $\$ 23,473.0$ million \\
\hline Expenditure (\%GDP) & $42,0 \%$ & $43.7 \%$ \\
\hline Exports & $\$ 264,013$ million & $\$ 44,766.5$ million \\
\hline Export ( \%GDP) & $44.6 \%$ & $83.5 \%$ \\
\hline Imports & $\$ 261,997,8$ million & $\$ 43,962.3$ million \\
\hline Imports ( \%GDP) & $44.2 \%$ & $81.8 \%$ \\
\hline Average annual wage (2015) & $\$ 23,035$ & $\$ 13,079$
\end{tabular}

These ports belong to the Baltic-Adriatic Corridor and are listed among 329 TEN-T core ports, which means their development will be supported by the EU, in particular the maritime access, hinterland connections and port sites. However, ports and port authorities still need to be proactive if they are to become more efficient and more competitive. This is especially the case with ports on enclosed seas. Due to their restricted communication with the open ocean, enclosed seas have some physical and economic particularities (Serry, 2020).

The authors compare the recent development of the Port of Koper and the Port of Gdansk by analysing five elements, namely, the ports' administration models, business strategies (throughput structure), hinterland and hinterland connections, and expansion plans. Within this analysis, they have identified key measures that have boosted the ports' development. In the final part of the paper, the transferability of the measures identified between the ports is discussed.

\section{INTRODUCTION TO THE SELECTED PORTS}

Ports are important for the European economy and its global competitiveness; almost 4 billion tons of cargo pass through European ports each year, with ports directly and indirectly employing approximately 3 million people. Ports are thus considered to be the drivers of socio-economic development in the regions they serve (e.g., Danielis \& Gregori, 2013; Jouili, 2016), which is especially true of the largest three Rotterdam, Antwerp and Hamburg - that account for approx. 20 $\%$ of European seaborne trade. However, this does not imply that smaller ports can be neglected.

\subsection{The Port of Koper}

The Port of Koper is Slovenia's only international cargo port. In six decades of operation, it developed from a singleberth port to a multipurpose port with 12 specialized terminals, each connected with public transport infrastructure by roads and railways. Annually, it handles around 20 million tons of cargo, including almost 1 million TEUs, and is visited by approximately 2,000 ships. The plan is to increase the port's throughput to 27 or even 35 million tons by 2030 (Luka Koper, 2015). The port, managed by public limited company Luka Koper, currently covers 280 hectares, has 3,300 meters of quays and 26 berths. The Port of Koper belongs to the association of North Adriatic ports that jointly handle around 120 million tons of cargo per year and devotedly promote the North Adriatic as the shortest route between the Far East and Central Europe. 


\subsection{The Port of Gdansk}

Poland has several international cargo ports, the most important of which are Gdansk, Gdynia, Szczecin, and Świnoujście. Polish ports realized 100 million tons of traffic for the first time in 2018 (Poland in, 2019), with the Baltic Sea region handling nearly 800 million tons of cargo (Serry, 2020), mainly attributable to Russian ports that export gas and oil.

The Port of Gdansk is the largest Polish port with almost 50 $\%$ share of total throughput (Poland in, 2019), in contrast to 39 $\%$ share in 2009 (Port of Gdansk, 2020a). The port takes up more than 1,065 hectares of land and is divided into two sectors, inner port, and outer port. This landlord port was called at by around 2,500 ships and handled over 52 million tons of various types of cargo in 2019. The ambitious plan, based on several stable pillars, is to double this volume by 2030 .

\section{THE COMPARISON OF THE SELECTED PORTS}

Though in 2009-2019, the throughput of the Port of Koper has in average increased by $5.8 \%$ per annum (AAGR), it reached as many as $11.4 \%$ per annum in Gdansk. In total, the throughput increased by almost $74 \%$ in Koper, and by nearly $177 \%$ in Gdansk.

Figure 1.

The throughput in the Port of Koper and in the Port of Gdansk.

Sources: authors, based on (Luka Koper, 2020); (Port of Gdansk, 2020a).

What are the reasons for the numbers that Gdansk is recording, and what can Koper learn from the Gdansk experience? To identify the answers, a closer look at the development of the ports over a longer period is required. The following chapters will thus focus on the differences between the two ports.

\subsection{Port Administration}

The Port of Gdansk Authority Spolka Akcyjna (i.e. joint stock company) was established in 1998. This company is the sole entity managing the port in Gdansk. It is owned by the State Treasury, the Municipality of Gdansk, and the entitled employees (IAPH, 2020). The Port of Gdansk is a landlord port, where the
Port Authority manages the port infrastructure, plans port development, acquires properties for port development needs, constructs, develops, maintains and upgrades port infrastructure, grants access to the port and port facilities, attracts outside investments and private capital, etc. The port's infrastructure is leased to 19 operators that provide cargo handling services.

On the other hand, the Port of Koper has a unique administration model. There is no Port Authority in Slovenia. Instead, Luka Koper, a public limited company in $51 \%$ state ownership, governs and manages the development of the Port of Koper, simultaneously acting as a concessionaire and performing cargo handling operations, as well as other value-added services on all terminals. 


\subsection{Port Hinterland}

The Port of Gdansk, rebuilt after its devastation in World War II, became the leading industrial and shipping centre of the Polish People's Republic and mainly served massive Polish and Soviet economy until early 1990s. Gdansk lost the once profitable and reliable (regardless of occasionally turbulent relationship) markets of the Soviet Union when the state disintegrated in late 1991. The hinterland of the port of Gdansk now consists of the Czech republic, Slovakia, Ukraine, Belarus, and Poland.

The construction of the commercial port of Koper commenced in the 1950s when it became clear that Trieste and its port would not belong to Yugoslavia. The Port of Koper helped the economy of Yugoslavia in its initial years of operation, but already by the mid 1970s, transit accounted for more than 50 $\%$ of its total throughput (Sadar, 1999). The war in the Balkans meant the loss of the Yugoslav markets, and the Port of Koper focused on the demands of Central Europe. Today, the hinterland of the Port of Koper mainly consists of Austria, Hungary, the Czech Republic, Slovakia, Croatia, northern Italy, and to a lesser extent, southern Germany and Poland.

As can be seen from the following figure, the Czech Republic and Slovakia are interesting markets for both ports.

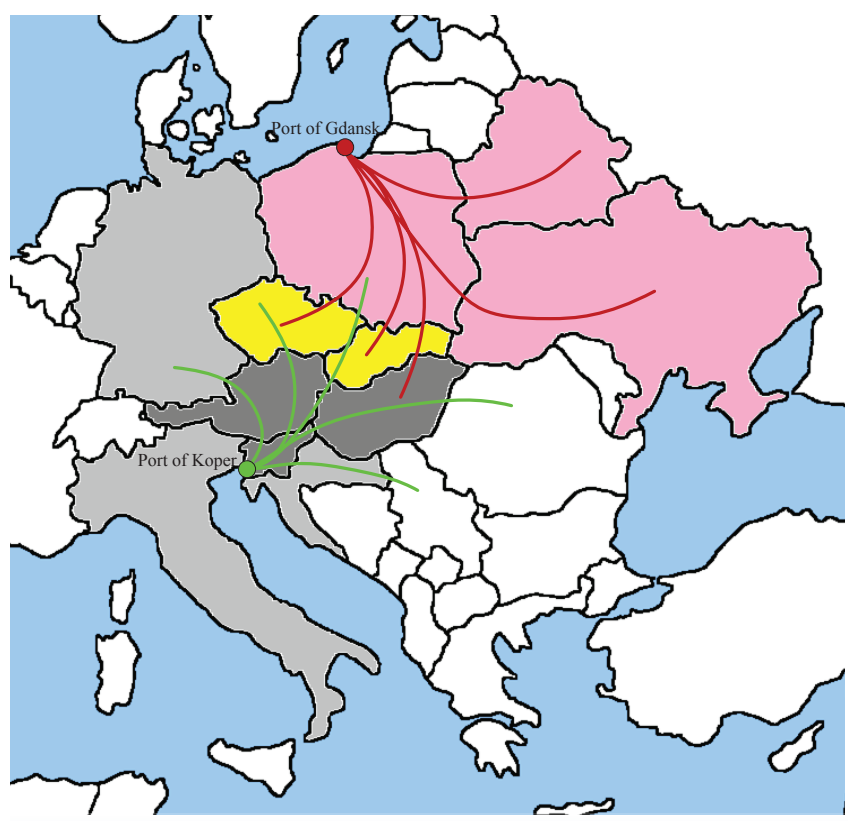

Figure 2.

The (overlapping) hinterlands of the Port of Koper and the Port of Gdansk.

Source: (Zanne \& Borkowski, 2020).

\subsection{Business Strategy}

Gdansk turned from bulk port into universal port and its primary role is container throughput, both in Poland and across the Baltic Sea region. Yet other cargo types have not been neglected either. Although liquid fuels, general cargo, coal, and grain have the highest share in the throughput of the Port of Gdansk, it also handles all other types of cargo. The reasoning of the Port Authority is that throughput diversity guarantees that turbulences affecting individual cargo groups will not have too great of an impact on the port, in spite of resources not being optimally used at certain limited time periods.

In that same period, the Port of Koper has prioritized containers and new cars, although it still handles majority of cargo types; the Port of Koper is the leading container port in the north Adriatic and the second largest car port in the Mediterranean region. While the port's car terminal cooperates with all major car manufacturers, the Port of Koper has no significant advantage when compared to other north Adriatic ports in terms of containers.

\subsection{Hinterland Connections}

Poland is planning to invest approximately EUR15.9 billion in the railway network by 2023. By 2019, around $60 \%$ of the National Railway Programme has been either completed or in progress, with EUR9 billion invested (RailwayPro, 2019). The EUR123 million investment in the modernisation of the railway line connecting the port, that included the laying of $30 \mathrm{~km}$ of new railway tracks, the construction of several flyovers and bridges, and the construction of a local rail traffic control centre, increased the rail traffic capacity of the junction six times (Port of Gdansk, 2020b).

The Port of Gdansk is likewise well-connected with the road network. The EUR210 million tunnel under the Martwa Wisla was first open to traffic in 2016. It connected the A1 motorway with the Port of Gdansk without affecting city traffic. The project was funded by the Gdansk Municipality and co-financed from the European funds (Port of Gdansk, 2020b).

Although Slovenia has a modern and safe motorway system and the Port of Koper recently got a new entrance, it is not yet fully operable, and as such has not relieved the congestion in the city, with around 1,000 trucks transiting to the port on a daily basis.

In general, the Slovenian railway infrastructure is outdated and limits rail transport (the delay of cargo trains was $122.1 \mathrm{~min}$ per $100 \mathrm{~km}$ in 2018 (Slovenian railways, 2019)); nevertheless, approximately $60 \%$ of the port's throughput (transhipment excluded) is realized by railway and the single electrified railway 
track connecting the port with its hinterland is at its maximum utilization level. $27 \mathrm{~km}$ of new railway tracks should be laid by 2026 at the cost of around EUR 1.3 billion.

\subsection{Port Expansion Plans}

Although the current estimated capacity of the Port of Gdansk is almost 100 million tons, and the utilization level is at around $50 \%$, expansion plans are already being made and are gargantuan. A three-stage EUR2.8 billion terminal complex of the new Central Port should include $19 \mathrm{~km}$ of new quays, $8.5 \mathrm{~km}$ of breakwaters, nine terminals for different types of cargo, four turning basins and three approach fairways (Safety4sea, 2019). The terminals will be used for containers, passengers, offshore operations, LNG operations, and shipbuilding. Priority selection will be market-driven.

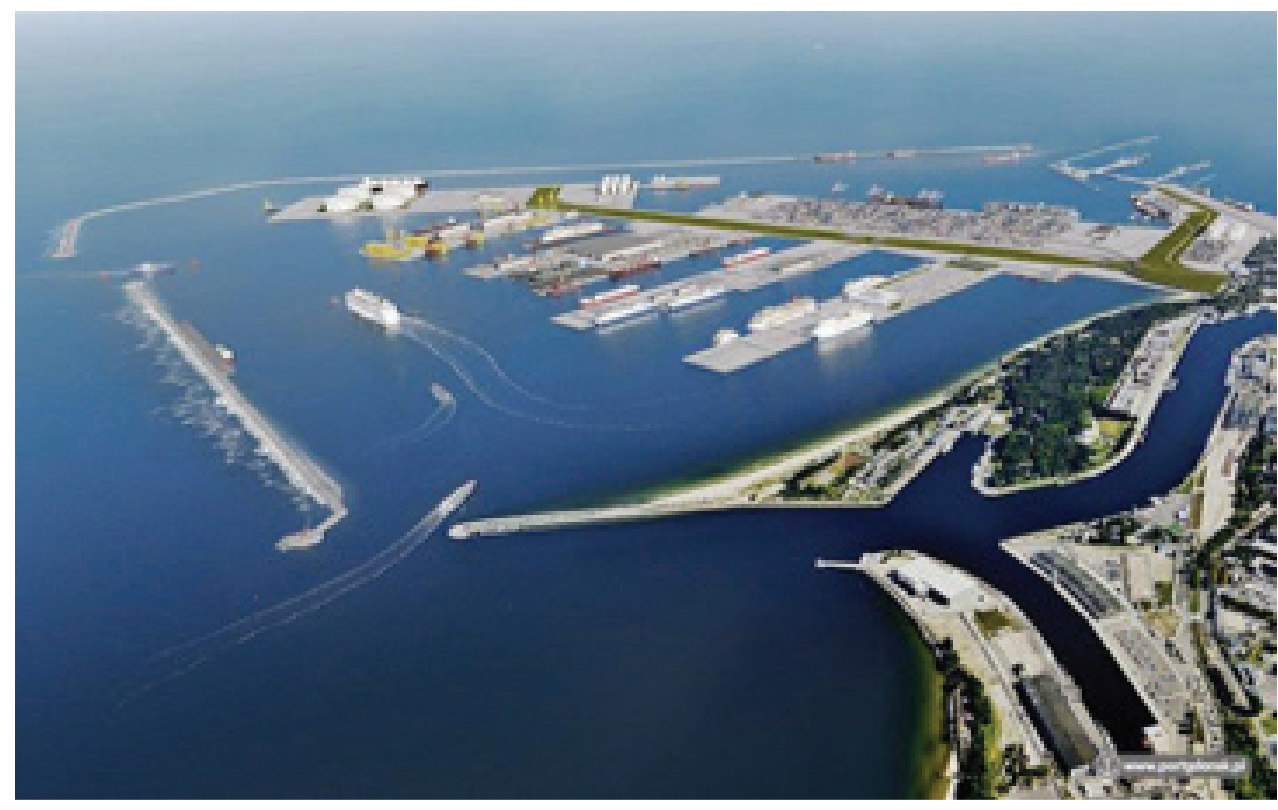

Figure 3.

Visualisation of the future Gdansk Central Port.

Sources: (Poland at Sea, 2019).

Though the port of Koper is about to reach its maximum throughput capacity, the port's area has not been expanded in over a decade, in spite of the doubled cargo throughput, and the fact that Slovenia's National Spatial Plan confirmed the port's expansion plans back in June 2011. Since then, some projects have been reconsidered (Pier III), and the Port of Koper is currently planning to invest EUR700 million in infrastructure and superstructure by 2030. These investments include (summarized from the Port of Koper, 2015): extension of Pier I and Pier II, extra storage areas, as well as the provision of railway tracks, improved road accesses, seabed dredging, and sediment disposal sites. Extension of Pier I is in progress, which will, once completed and equipped, increase container terminal capacity to 1.5 million TEU. The estimated value of this project is EUR235 million.

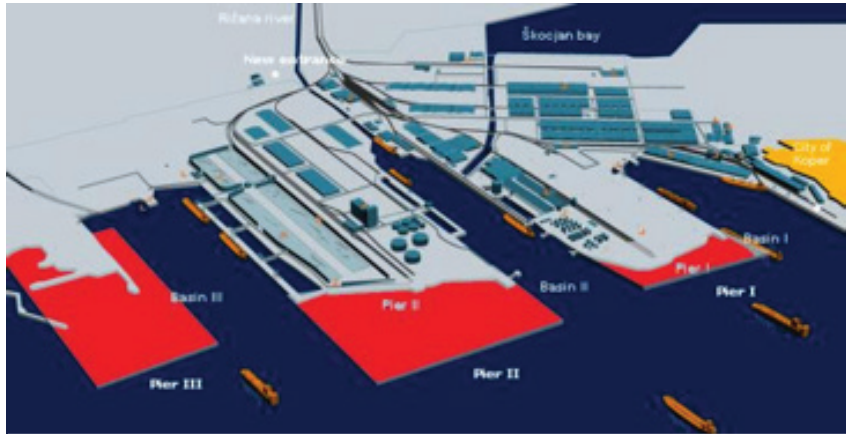

Figure 3.

Expansion plans for the Port of Koper. Source: (Port of Koper, 2012). 


\section{DISCUSSION}

The hinterlands of both ports have great economic potential, giving them a reason for optimism, as cargo concentration in the hinterland is expected to grow. However, which port will seize control of the Czech and Slovak market depends on a variety of other factors, since ports no longer compete only with the seaside, but with the landside offer as well.

The favourable geostrategic position of the Port of Koper has been emphasized for more than two decades; Koper and other North Adriatic ports are the shortest sea-route between Asia and Central Europe. However, not much has been done with respect to the port's access to transport infrastructure and the development of hinterland infrastructure, in particular railways, that would further enhance the port's position (Zanne \& Borkowski, 2020). On the other hand, the Port of Gdansk is already capable of accommodating even the largest ships. Likewise, the Covid-19 lockdowns reduced bunker costs and decreased the use of the Suez Canal, demonstrating that Mediterranean ports, and especially Adriatic ports, can be easily omitted from the AsiaEurope routes. However, this situation is far from normal, and present delivery times would usually be completely unacceptable (another welcome benefit is the artificially decreased merchant fleet capacity). Once the economy recovers, bunker prices will return to normal levels. In addition, regardless of huge railway investments, Poland has still not achieved $100 \%$ compliance with EU requirements for the Baltic-Adriatic corridor, though, it is admittedly making better progress than Slovenia.

Studies (OECD/ITF, 2008; de Langen, 2008; Tongzon, 2009) have shown service quality and port competitiveness to diminish as the port or its hinterland connections approach their maximum utilization capacity. Service provision deadlines are extended, increasing costs and reducing service reliability.

The Port of Gdansk has enjoyed the support of local and national authorities. Its landlord port management model and successful operation allow it to efficiently attract private capital and plan for a massive expansion. Recently, the connection of the Port of Gdansk with the national transport networks has been improved, and the port can further develop without impeding the development of the city or weakening the positive relationship between the port and the local community. Likewise, Poland is the fastest growing and seventh-largest economy in the EU, with the total GDP of EUR590 billion. With its 40 million inhabitants and well-developed industry, it is in itself an important market for the nation's ports, while the relatively good hinterland connections link it with the market of additional 120 million people (Zanne \& Borkowski, 2020).

The Port of Koper has limited expansion options; as it is surrounded by urban and reserved natural areas from three sides, its only option for expansion, which is also limited, is the sea. The unique administrative model of the Port of Koper, where Luka Koper simultaneously performs the function of the Port Authority and concessionaire, is not beneficial either. The Port of Koper is organized neither as a standard service port, nor as a corporatized port. Still, it has some of the weaknesses of both models, mainly the mix of public and private objectives, inefficiency due to the lack of internal competition, limited access to state funds, and reduced problem-solving capacity and flexibility in case of labour problems (Zanne \& Borkowski, 2020). The inability to determine the ownership of shares in the Luka Koper company precludes restructuring; yet, fresh capital is sorely needed if the Port of Koper is to maintain its good position among north Adriatic ports.

The Port of Koper lost some cargo in 2019. This was the first decrease in throughput since 2009, with the distinction that back then, in contrast to 2019, it could be attributed to global economic crisis. Though other Adriatic ports also lost some cargo in 2019, Koper suffered a far greater decline, suggesting that some cargo shifting has occurred in the region. On the other side of the Baltic-Adriatic corridor, the Port of Gdansk continued to increase its throughput in 2019. This unexpected decline of throughput in the Port of Koper should be cause for alarm; the port and the state must improve their cooperation, and develop a restructuring model for the port. In addition, the strategy to mainly focus on two cargo types can be rather dangerous; the volatility of the automobile market was clearly visible in 2009, when the port handled $45 \%$ fewer cars than in 2008. The competition in the container segment is fierce, with 5 large ports situated in the radius of $100 \mathrm{~km}$.

\section{CONCLUSIONS}

The Port of Gdansk is the fastest-growing port in Europe that largely owes its success to the deep-water container terminal (DCT). Its unique location, in the ice-free zone of the southern Baltic Sea, makes it the ideal gateway port for Central and Eastern Europe and the transhipment hub for the Baltic.

Though the Port of Koper cannot replicate the volumes realized by the Port of Gdansk (mainly due to its limited expansion possibilities), it can improve its position in the north Adriatic by systematically copying the steps taken by the Port of Gdansk. Simultaneously, Slovenia needs to understand the value of the port for the national economy. Port expansion plans must go hand in hand with the development of hinterland connections; expanding the port without simultaneously increasing the capacity of hinterland connections would result in sub-optimal use of the resources and poor port performance indicators.

In this paper, the authors analysed the elements affecting port operation and examined the possibility of implementation of certain measures in the Port of Koper. The analysis is not 
supported by quantification. In future research, the authors will analyse the time series for both ports to quantify the effects of the measures on port performance.

\section{NOTICE}

This work is an expanded version of paper presented on $19^{\text {th }}$ International Conference on Transport Science (ICTS 2020), Portorož, Slovenia, 17 - 18 September 2020.

\section{REFERENCES}

Alderton, P., 2008. Port management and operations (3rd ed.). London: Informa.

CountryEconomy, 2020. (September). Country comparison Poland vs Slovenia. Available at: https://countryeconomy.com/countries/compare/poland/slovenia.

Danielis, R. \& Gregori, T., 2013. An input-output-based methodology to estimate the economic role of a port: The case of the port system of the Friuli Venezia Giulia Region, Italy. Maritime Economics \& Logistics, 15(2), pp.222-255. Available at: http://dx.doi.org/10.1057/mel.2013.1.

de Langen, P. W., 2008. Ensuring hinterland access; the role of port authorites. Research round table, Paris 10-11, April 2008.

IAPH, 2020. Welcome to a new member port from Poland. International Association of Ports and Harbors. Available at: https://www.iaphworldports.org/news/7228.

Luka Koper, 2015. Summary of Luka Koper d.d. and the Luka Koper Group Business Strytegy until 2030 and the Company's and Group's Startegic Business Plan 20162020, Koper: Luka Koper.

Luka Koper, 2012. Projects - Port Handbook. Available at: http://www.luka-kp.si/ eng/port-handbook.

Luka Koper, 2020. Detailed throughput statistics. Available at: https://www.luka-kp. si/eng/311.

OECD/ITF, 2008. Port competition and hinterland connections: Summary and conclusions. Paris: OECD/ITF.

Poland at Sea, 2019. This is what the Central Port in Gdansk is going to look like. Available at: Poland at Sea - maritime economy portal - http://www.polandatsea. com/this-is-what-the-central-port-in-gdansk-is-going-to-look-like/.
Poland in 2019. Transhipments in Polish seaports exceeded 100 million tons: ministry. Available at: Poland in - https://polandin.com/40886067/transhipmentsin-polish-seaports-exceeded-100-million-tons-ministry.

Port of Gdansk, 2020a. Facts and figures: Cargo statistics. Available at: Port of Gdansk - http://www.portgdansk.pl/about-port/facts-and-figures.

Port of Gdansk, 2020b. Investments carried out in recent years. Available at: Port of Gdansk - https://www.portgdansk.pl/about-port/investments-carried-out-inrecent-years

RailwayPro, 2019. Poland's National Railway Programme is at its halfway. Available at: https://www.railwaypro.com/wp/polands-national-railway-programme-is-at-itshalfway/.

Sadar, K., 1999. Luka Koper - The Port of Koper. Geografski vestnik, 67, 55-78. Available at: http://zgs.zrc-sazu.si/Portals/8/Geografski_vestnik/Pred1999/ GV 6701055 078.pdf.

Safety4sea, 2019. Port of Gdansk announces expansion plans. Available at: https:// safety4sea.com/port-of-gdansk-announces-expansion-plans/.

Serry, A., 2020. Shipping in peripheral seas: The case of Baltic Sea region and Adriatic Sea. 19th International Conference on Transport Science, pp. 289-295.

Slack, B., 1985. Containerization, inter-port competition, and port selection. Maritime Policy \& Management, 12(4), pp.293-303. Available at: http://dx.doi.org/10.1080/03088838500000043.

Slovenian railways, 2019. Annual report 2018. Ljubljana: Slovenian railways.

Tongzon, J.L., 2002. Port choice determinants in a competitive environment International Association of Maritime Economists - IAME. Panama.

Tongzon, J.L., 2009. Port choice and freight forwarders. Transportation Research Part E: Logistics and Transportation Review, 45(1), pp.186-195. Available at: http://dx.doi.org/10.1016/j.tre.2008.02.004.

UNCTAD, 2019. Review of maritime transport. Geneva: United Nations Conferenceon Trade and Development.

Zanne, M., \& Borkowski, P., 2020. Overcoming growth barriers in regional port development. 19th International Conference on Transport Science, pp. 390-395. Portoroz: Faculty of Maritime Studies and Transport. 